\title{
Physical Conditioning Index on Active Elderly Population
}

\begin{abstract}
Fabiana Rodrigues Scartoni*1,2, Matheus Freitas Pércia Rabello² ${ }^{2}$ Samuel Nascimento Ramos da Silva ${ }^{2}$, Leandro de Oliveira Sant’Ana ${ }^{2,5}$, Estevão Scudese ${ }^{1,2}$, Ayrton Moraes Ramos ${ }^{4}$, Gilmar Weber Senna ${ }^{1,2}$, Antonio Alías Garcia ${ }^{3}$ and Estélio Henrique Martin Dantas ${ }^{1,4}$
\end{abstract}

${ }^{1}$ Nursing and Biosciences Post -Graduation Program, Brazil

${ }^{2}$ Sports Science and Exercise Laboratory (LaCEE), Brazil

${ }^{3}$ Universidad de Almería, Spain

${ }^{4}$ Health and Environmental Post-Graduation Program (PSA), Brazil

${ }^{5}$ Laboratory of Research and Studies in Strength Training of the Federal University of Juiz de Fora, MG (LabFor)

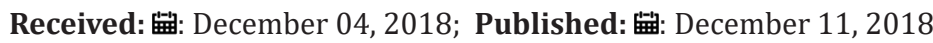

*Corresponding author: Fabiana R Scartoni, Nursing and Biosciences Post -Graduation Program, Brazil

\begin{abstract}
Issues regarding the human aging process have become the focus of discussions and investigations around the world. Inevitably, this process is associated with physiological changes such as modifications in body composition that are related to progressive declines in the biological function as well as the presence of chronic and locomotor impairment conditions, which besides life- threatening risk, pose a challenge to the elderly independence and autonomy. The proposal of an active aging has been strengthened with training programs that seek to improve physical fitness. There are several factors that comprise physical conditioning such as: aerobic resistance, body composition; muscular strength, localized muscular endurance, neuromotor abilities and flexibility, which are important components to maintain the independence of the elderly, since there is direct influence on the functional autonomy. Within these components, the musculoskeletal system is considered the core of the elderly physical health, which consists of three major pillars: muscular strength, aerobic resistance and flexibility. Although there are a considerable number of tests that evaluate physical conditioning, intending to optimize and facilitate the diagnostic evaluations for a satisfactory prescription, it was necessary to compile a battery of tests that contemplated variables of the physical fitness of the elderly to enhance evaluation, prescription and supervision of the exercise programs proposed by health professionals. With this in mind, the Latin American Maturity Development Group (GDLAM) sought to associate a battery of tests that could approximate the reality of activities performed in daily life. From this compilation of tests, it was possible to measure the physical fitness index and functional capacity of the active elderly population.
\end{abstract}

Keywords: Physical Fitness; Elderly

\section{Mini Review}

The human aging process is currently at the center of a worldwide discussion from the scientific community engaged to provide accurate and efficient strategies around different physical activity modalities [1]. Inevitably, this natural process is associated with deleterious physiological changes among variations in body composition, body dimensions and more specifically, in height, weight, and waist circumference. These changes are related to progressive declines in the function of biological systems [2,3] as well as the development of chronic/locomotor conditions, which in addition to the life-threatening potential, may cause a considerable detriment effect on the elderly population autonomy. These physiological modifications, mainly those related to muscle waste process and joint impairments, associated with a physical inactivity status, can amplify the degenerative condition of the elderly physical and physiological capacities [4]. On the other hand, the regular practice of physical exercises can be an essential tool for the treatment of chronic degenerative diseases [5,6], has a neuroprotective and preventive effect on the development of neurodegenerative diseases [5], associated to the improvement of cognitive function (MURMAN, 2015), daily tasks [7] and also considered as an effective way to prevent or even revert the decline of the functional capacity of the elderly [8].

The proposal of active aging practicing physical exercises has been strengthened with the creation of training programs that seek 
the improvement of the physical conditioning, conceptualized as the state of physical development, hygienic habits, and the level of accomplished training that a person presents [9]. Currently, there is a consensus that the core of the elderly physical health is the musculoskeletal system, which consists of three major components: muscular strength, aerobic endurance, and flexibility [10-12]. According to the American College of Sports Medicine (2011) Several key factors comprise physical conditioning, such as aerobic resistance, muscle strength, localized muscular endurance, flexibility, and body composition. These components are essential for (maintaining independence over the course of the aging process and its influence on the functional autonomy has been demonstrated by different investigations $[8,14,15]$.

Other studies also report benefits of the regular exercise practice on the neuromuscular [16-20]and cardiovascular system $[15,21,22]$ evidencing the importance of the scientific theoretical knowledge applied to daily training, with reliable testing tools, and technical supervision enhancing the efficacy for this population.

Although there are a considerable number of tests that evaluate physical fitness [23] and in order to optimize and facilitate the diagnostic evaluations for a satisfactory prescription, it was necessary to compile a battery of tests that included the fitness variables of the elderly to enhance evaluation, prescribe and supervise the exercise programs proposed by health professionals. Within this context, having physical exercise as a practice that involves planning and systematization for maintenance or even improvement of physical fitness [24] it become necessary the prior evaluation of the variables that compose the physical fitness for the adequate prescription of training programs directed to the elderly [25]. In this scenario, the Latin American Maturity Development Group (GDLAM) sought to associate a battery of tests that could approximate the reality of activities performed in daily life [26]. From this test battery created according to the Group's protocol (GDLAM), it became possible to measure the physical fitness index and the functional capacity of the elderly physically independent [27]. The battery consists of tests that include the evaluation of these five components using the following protocols:

a) Body Composition: two factors are evaluated. The first Body Mass Index - BMI consisting of dividing body mass by the square of height. In order to classify the nutritional status of the elderly, the cut-off points are used [28]. To evaluate the lean mass, the calf circumference is used as the parameter that provides the most sensitive indirect measure of this component [29];

b) Aerobic Resistance: Six-minute test proposed by the American Thoracic Society [30] for verifying V02 max consumption; consists of walking as far as possible within 6 minutes in a path of 45.72 meters marked every $4.57 \mathrm{~m}$ by $15 \mathrm{x}$ $5 \mathrm{~cm}$ rectangles. The walking area can be elaborated in an open or closed environment; however, it must be conducted on a welllit area with a non-slip surface. If necessary, the subjects may stop to rest and return to the test. The total distance traveled gives the result compared to the reference values proposed by the protocol for men and women. Then the estimated VO2max is calculated using the following calculation: $\mathrm{VO} 2 \mathrm{max}=0.03 \mathrm{x}$ distance (meters) + 3.98 [31].

c) Localized Muscle Endurance: The upper limbs are evaluated by elbow flexion and extension test where the subject remains sited on a chair holding pronated a twokilogram weight on the dominant arm with the hand and wrist parallel to the forearm and then perform as many complete movements as possible in a 30 -second time length. The lower limbs test is performed by sitting and standing-up test, in a chair without arm supports, with the seat padding $43 \mathrm{~cm}$ height from the ground and maintain the arms crossed in front of the chest the subject must repeat the highest number of complete movements in a 30-second window [32].

d) Strength: In order to test for strength, the subjects perform elbow flexion and extension tests and the sit and stand-up tests in the same 30-second time length as the previously described test, with a barbell for upper and lower limbs respectively [32]. The barbell is standardized as $7 \mathrm{~kg}$ for female and $11 \mathrm{~kg}$ for the male. For the elbow flexion and extension test, the hand width positioning is made with a distance equal to or slightly higher than the distance between the shoulders with the hands in a pronation position. As for the sit and stand-up test, the barbell is positioned and supported on the trapezius muscle.

e) Flexibility: The Normal flex is a dimensionless test elaborated to measure flexibility, which aims to minimize the issues encountered by health professionals when facing large groups of individuals with small periods to perform the tests. Among its characteristics, there is no need for equipment, rigorous methodological procedures, and even evaluators, since the subject tested will perform the movements without an instructor's help. Seven movements comprise the test, divided into four execution possibilities for each, where a classification translated as a score of 0 to 3 is assigned. Insufficient - 0 ; regular -1 ; good -2 and very good -3 . The values sum will classify the flexibility of the Elderly according to the extent achieved. The movements that comprise the test are related to daily skill activities, primarily reflecting the individual's autonomy and independence to perform tasks that enable him to comb his hair, wear a coat, wash his back, put on a shoe, and so on [33].

From the results obtained in the tests, the physical fitness index (ICF) of the elderly was established [26] by applying a weighted average that compensates for the brute value of each variable expressed by the following calculation:

ICF: $\{[($ upper LME/6 + lower LME/7)/2] + FI + (VO2/4,3) + $(\mathrm{BMI} / 9,3)+(\mathrm{S} / 7,15)\} / 5$

ICF: Physical Fitness Index; upper_LME: Upper Limbs Localized Muscle Strength; lower_LME: Lower Limbs Localized Muscle Strength; FI: Flexibility Index (weighted average from NORMALFLEX); VO2: estimated oxygen consumption value (sixminute test); BMI: Body Mass Index; S: Strength Variable. 
Considering all the data and information described, it can be concluded that the evaluation, prevention, and maintenance of the functional capacity of the elderly associated with regular physical exercise in order to improve functional capacity, possesses an extreme importance and can be easily assessed by the ICF, a functional, accessible and user-friendly strategy for testing the elderly population.

\section{References}

1. Le Pham Phu Dac, VO TQ (2015) Assessment of psychometric properties of WHOQOL-OLD instrument: A literature review. Int J Pharm Pharm Sci 4: 53-66.

2. Shumway-Cook A, Silver IF, LeMier M, York S, Cummings P, et al. (2007) Effectiveness of a community-based multifactorial intervention on falls and fall risk factors in community- living older adults: A randomized, controlled trial. Journals Gerontol Ser a Biol Sci Med Sci 62(12): 14201427.

3. Foldvari M, Clark M, Laviolette LC, Bernstein MA, Kaliton D, et al. (2000) Association of muscle power with functional status in communitydwelling elderly women. Journals Gerontol Ser a Biol Sci Med Sci 55(4): M192-M199.

4. Inouye K, de Souza Orlandi F, Pavarini SCL, Pedrazzani ES (2018) Efeito da Universidade Aberta à Terceira Idade sobre a qualidade de vida do idoso. Educ e Pesqui 44: 142931.

5. Coelho FG de M, Gobbi S, Andreatto CAA, Corazza DI, Pedroso RV, et al. (2013) Physical exercise modulates peripheral levels of brain-derived neurotrophic factor (BDNF): A systematic review of experimental studies in the elderly. Arch Gerontol Geriatr 56(1): 10-15.

6. Foster PP, Rosenblatt KP, Kuljiš RO (2011) Exercise-induced cognitive plasticity, implications for mild cognitive impairment and Alzheimer's disease. Front Neurol 2: 28.

7. Raichlen DA, Alexander GE (2017) Adaptive Capacity: An Evolutionary Neuroscience Model Linking Exercise, Cognition and Brain Health. Trends Neurosci 40(7): 408-421.

8. Vale RGS, Pernambuco CS, Dantas EHM (2016) Manual de avaliação do idoso, pp. 208.

9. Dantas EHM (2014) A prática da preparação física (6a edn); Grupo Gen - Editora Roca Ltda, Rio de Janeiro.

10. Doherty TJ (2003) Invited review: Aging and sarcopenia. J Appl Physiol 95(4): 1717-1727.

11. Morley JE, Abbatecola AM, Argiles JM, Baracos V, Bauer J, et al. (2011) Sarcopenia with limited mobility: An international consensus. J Am Med Dir Assoc 12(6): 403-409.

12. Wallerstein LF (2010) Influência dos treinamentos de força e potência nas adaptações neurais, morfológicas e na funcionalidade em idosos.

13. Garber CE, Blissmer B, Deschenes MR, Franklin BA, Lamonte MJ, et al. (2011) Quantity and Quality of Exercise for Developing and Maintaining Cardiorespiratory, Musculoskeletal, and Neuromotor Fitness in Apparently Healthy Adults. Med Sci Sport Exerc 43(7): 1334-1359.

14. Cipriani NCS, Meurer ST, Benedetti TRB, Lopes M (2010) Aptidão Funcional de Idosas Praticantes de Atividades Físicas. Rev Bras Cineantropometria E Desempenho Hum 12(2): 106-111.

15. Fraga MJ, Cader SA, Ferreira MA, Giani TS, Dantas EHM (2011) Aerobic resistance, functional autonomy and quality of life (QoL) of elderly women impacted by a recreation and walking program. Arch Gerontol Geriatr 52(1): e40-e43

16. Borba-Pinheiro CJ, Carvalho MCG de A, Silva NSL da, Bezerra JCP, Drigo AJ, et al. (2010) Efeitos do treinamento resistido sobre variáveis relacionadas com a baixa densidade óssea de mulheres menopausadas tratadas com alendronato. Rev Bras Med do Esporte 16(2): 121-125.

17. de Araújo Alencar N, Bezerra JCP, Dantas EHM (2009) Avaliação dos níveis de atividade física, autonomia funcional e qualidade de vida de idosas integrantes do programa de saúde da família. Fit Perform J 8(5): 315-321.

18. de Souza Vale RG, de Oliveira RD, Pernambuco CS, da Silva Novaes J, de Andrade A de FD (2009) Effects of muscle strength and aerobic training on basal serum levels of IGF-1 and cortisol in elderly women. Arch Gerontol Geriatr 49(3): 343-347.

19. Hoefelmann CP, Benedetti TRB, Antes DL, Lopes MA, Mazo GZ, et al. (2011) Aptidão funcional de mulheres idosas ativas com 80 anos ou mais Functional fitness of elderly active women aged 80 or more. Mot Rev Educ Fis 17(1): 19-25.

20. Ribeiro L dos S, Triani F da S, Júnior CA de OM, Carvalho GS de (2018) 0 processo de envelhecimento e o equilíbrio: A contribuição do exercício físico na promoção da saúde dos idosos p. 43-52.

21. Blanhir JEM, Vidal CDP, Romero MJR, Castro MMG, Villegas AL ZM (2011) Teste de caminhada de seis minutos: Uma ferramenta valiosa na avaliação do comprometimento pulmonar. J Bras Pneumol 37(1): 110117.

22. de Assis CCA, da Silva JAS, Paiva JTS, Couto LB, de Souza SSF, et al. (2018) Agravos Ee Riscos à Saúde do Idoso Relacionado ao Sistema cardiovascular: Hipertensão Arterial e Acidente Vascular Cerebral. Biológicas \& Saúde 8(27).

23. Gama HS, Yamanishi JN, Gallo LH, Valderramas SR, Gomes ARS (2018) Exercícios de alongamento: prescrição e efeitos na função musculoesquelética de adultos e idosos/Stretching exercise: Prescription and effects on musculoskeletal function in adults and elderly people. Cad Bras Ter Ocup 26(1).

24. Strath S, Kaminsky L, Ainsworth B, Ekelund U, Freedson P, et al. (2013) Guide to the assessment of physical activity: Clinical and research applications: A scientific statement from the American Heart Association. Circulation 128(20): 2259-2279.

25. Ferreira JM (2017) Indicadores de qualidade na atenção primária á saúde no Brasil: Uma revisão integrativa. Rev Ciência Plur 3(3): 45-68.

26. Sena P, Guimarães A, Melo A, Dantas EHM (2017) Índice de Condicionamento FÍsico Conforme o protocolo GDLAM: Uma revisão de literatura. Cad Grad - Ciências Biológicas e da Saúde 4(1): 153-172.

27. Del Duca GF, da Silva MC, da Silva SG, Nahas MV, Hallal PC (2011) Incapacidade funcional em idosos institucionalizados. Rev Bras Atividade Física Saúde 16(2): 120-124.

28. Lipschitz DA (1994) Screening for nutritional status in the elderly. Prim Care 21(1): 55-67.

29. Pagotto VI, Ferreira dos Santos KI, Gomes Malaquias SI, Márcia Bachion MI, Aparecida Silveira EI (2018) Calf circumference: Clinical validation for evaluation of muscle mass in the elderly. Rev Bras Enferm 71(2): 343-350.

30. ATS (2002) Guidelines for the six-minute walk test. Am J Respir Crit Care Med 166(1): 111-117.

31. Cahalin L, Mathier M, Semigran M, Dec GW, DiSalvo T (1996) The sixminute walk test predicts peak oxygen uptake and survival in patients with advanced heart failure. Chest 110(2): 325-332.

32. Rikli RE, Jones CJ (1999) Development and validation of a functional fitness test for community-residing older adults. J Aging Phys Act 7(2): 129-161.

33. Varejao R V, Figueira HA, Figueira A, Conceicao MCSC, Vale RGS, et al (2014) Reproducibility of Normal Flex tests in evaluating the flexibility of elderly women. Research 1: 1266. 


\section{ISSN: 2574-1241}

DOI: $10.26717 / B J S T R .2018 .11 .002177$

Fabiana R Scartoni. Biomed J Sci \& Tech Res

(C) This work is licensed under Creative

Submission Link: https://biomedres.us/submit-manuscript.php

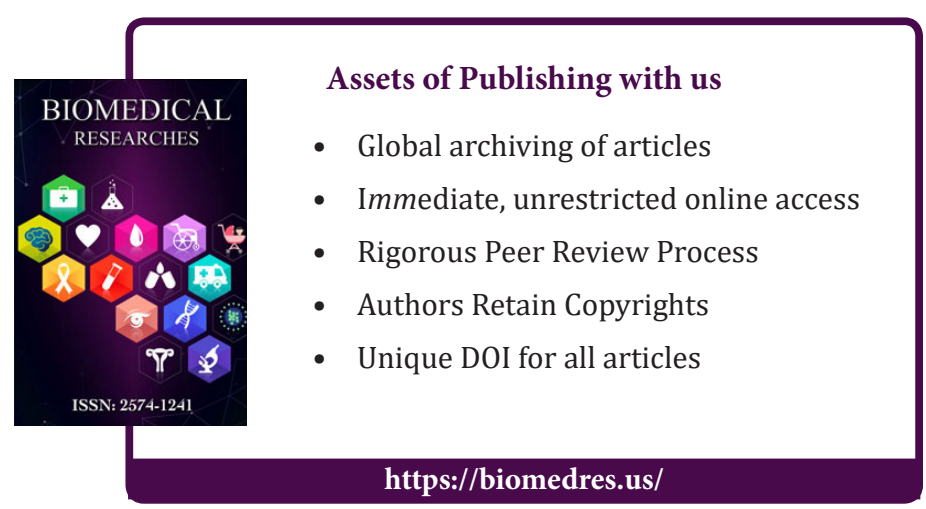

